Article

\title{
Evaluation of Shrimp Waste Valorization Combining Computer-Aided Simulation and Numerical Descriptive Inherent Safety Technique (NuDIST)
}

\author{
Antonio Zuorro ${ }^{1, *(\mathbb{D})}$, Daylisney Cassiani-Cassiani ${ }^{2,+}$, Demmy A. Meza-González ${ }^{2,+}$, \\ Kariana Andrea Moreno-Sader ${ }^{2}$ and Ángel Darío González-Delgado ${ }^{2, *}$ \\ 1 Department of Chemical Engineering, Materials \& Environment, Sapienza University of Rome, \\ Piazzale Aldo Moro, 00185 Rome, Italy \\ 2 Chemical Engineering Department, Nanomaterials and Computer Aided Process Engineering Research \\ Group (NIPAC), University of Cartagena, Avenida del Consulado St. 30 \#48B-152, \\ 130015 Cartagena de Indias, Colombia; dcassianic@unicartagena.edu.co (D.C.-C.); \\ dmezag@unicartagena.edu.co (D.A.M.-G.); kmorenos@unicartagena.edu.co (K.A.M.-S.) \\ * Correspondence: antonio.zuorro@uniroma1.it (A.Z.); agonzalezd1@unicartagena.edu.co (Á.D.G.-D.) \\ + These authors contributed equally to this work.
}

Received: 8 July 2020; Accepted: 31 July 2020; Published: 2 August 2020

\begin{abstract}
Nowadays, inherently safer designs are considered as key priorities to prevent or mitigate serious incidents with devastating consequences. The need for process safety assessment during early design phases has motivated the development of several contributions related to computer-aided assessment methodologies to measure the inherent safety of chemical processes. In this work, the large-scale production of chitosan from shrimp wastes was evaluated from a process safety point of view using the numerical descriptive inherent safety technique (NuDIST). To this end, simulation of the chitosan production was performed using Aspen Plus ${ }^{\circledR}$ to obtain extended mass and energy balances. The assessment of all the chemicals involved within the process was carried out for the following safety parameters: explosivity (EXP), flammability (FL), and toxicity (TOX). The safety assessment of the process included the parameters of temperature $(\mathrm{T})$, pressure $(\mathrm{P})$, and heat of reaction (HR). The maximum chemical safety score was estimated in 171.01 with ethanol as the main contributor to the parameters of explosivity and flammability. The score associated with operating data was calculated at 209.20 and heat of reaction reported to be the most affecting parameter. The NuDIST score was estimated at 380.20. This NuDIST value revealed the low hazards associated with the handling of substances such as shrimp wastes, chitosan, and water, as well as the non-extreme temperature and pressure conditions. In general, the large-scale production of chitosan from shrimp shells was shown to be an inherently safe alternative of waste valorization.
\end{abstract}

Keywords: chitosan; process safety; NuDIST; CAPE; shrimp

\section{Introduction}

The increasing demand for shrimp worldwide has motivated shrimp industries to raise their production capacity generating a higher amount of wastes. Such wastes are mainly composed of cephalothorax, shell, and tail, which represent approximately $50 \%$ of the total shrimp weight [1]. Globally, the waste generation rate is around 1.4 billion ton/year [2]. Colombia, the Caribbean and Pacific coasts mostly process shrimps according to market needs and have been environmentally affected by the generation of shrimp wastes. The major environmental issues are related to exoskeleton decomposition and attraction of insects, as well as diseases transmitted to humans [3]. 
To solve environmental-related problems of shrimp wastes generation, different alternatives such as valorization of residues and production of high-value materials have been proposed. Due to the high content of chitin and carotenoids in shrimp exoskeleton (about 20-30\%), shrimp wastes are known as a promising source of chitosan and astaxanthin [4]. Chitosan is produced by enzymatic or chemical deacetylation of chitin [5]. This biopolymer is biocompatible, biodegradable, non-toxic, and exhibits a wide range of applications in the textile, pharmaceutical, and food industries, among others [6]. Chitin and chitosan are of commercial interest because of their high percentage of nitrogen $(6.89 \%)$ compared to synthetically-substitute cellulose $(1.25 \%)$ and this makes chitin a useful chelating agent [7]. Astaxanthin is extracted using alkaline solutions at high concentrations and temperatures, without performing depigmentation processes to take advantage of such byproduct [8]. It is a red carotenoid pigment classified as a xanthophyll, that occurs naturally in a wide variety of living organisms [9]. This carotenoid has several applications in the cosmetic, pharmaceutical, medicinal, and health supplement industries [10].

The extraction procedures for high-value products from shrimp wastes have been the focus of several contributions. Despite these efforts, there is still a knowledge gap in the application of computer-aided assessment tools to evaluate the performance of chitin, chitosan, and astaxanthin production from shrimp exoskeleton and identify improvement opportunities. One of the most important analyses to consider is safety assessment. Major accidents have taken place in several industries causing economic loss, physical damage, and death of employees and loss of reputation and credibility in the industry [11]. Therefore, the importance of safety analysis becomes evident. The main objective of process safety assessment is to eliminate all hazards, or else to mitigate the consequences of these [12].

Different metrics have been proposed for quantification and measurement of safety performance. Gerbec [13] proposed a new universal safety indicator method to support organizational learning in process-safety incident investigation, which was determined from the outcome deficiency observations and root-cause analysis of company incident investigations. Jafari et al. [12] stated the contribution of the index-based approach to measuring the inherent safety of the chemical process design and performed a systematic review of novel indicators developed within the period 1990-2017. They identified 35 indicators categorized according to the estimation approach (hybrid approach, equational based approach, graphical approach, advanced mathematical approach, risk-based approach, and relative ranking). Some of the most popular have been the fuzzy-logic-based inherent safety index, the process stream index, the integrated inherent safety index, and the fire and explosion index. For early design phases, inherent safety metrics are widely employed, for example, the numerical descriptive inherent safety technique (NuDIST). This metric is a universal safety indicator method to support organizational learning in process safety incident investigation [14].

According to the contributions shown in Table 1, there is limited open literature regarding the application of NuDIST assessment methodology in chemical processes whose process data is gathered from modeling and simulation. Despite the efforts of such techniques to overcome the limitations of conventional index-based methods for safety assessment, it was identified that there is a need to explore the use of the NuDIST metric as a decision-making tool for inherent safety designs of additional chemical processes. In this work, the NuDIST methodology is used to evaluate the performance of large-scale production of chitosan from shrimp wastes from a process safety point of view. This is the first time that process safety aspects have been analyzed at the early design phase for a scaled-up process to obtain chitosan. The incorporation of computer-aided simulation allows for the entering of more detailed process data in the calculation of the chemical and process safety index involved in the NuDIST index. 
Table 1. Summary of contributions about the application of the numerical descriptive inherent safety technique (NuDIST) tool and process simulation on chemical processes.

\begin{tabular}{lccc}
\hline \multicolumn{1}{c}{ Chemical Processes } & Process Simulation & NuDIST Technique & Reference \\
\hline Methyl methacrylate manufacturing & & + & {$[14]$} \\
\hline Biodiesel production & & + & {$[15]$} \\
\hline Catechol production from lignin & + & & {$[16]$} \\
\hline Fermentative hydrogen production from food waste & + & + & {$[17]$} \\
\hline Palm oil recovery & & + & {$[18]$} \\
\hline Hydrodealkylation process & & & {$[19]$} \\
\hline Furfural and biogas production using pentoses & + & {$[20]$} \\
\hline Production of chitosan from shrimp wastes & + & + & This work \\
\hline
\end{tabular}

\section{Methodology}

The general methodology applied for the process safety assessment of chitosan production from shrimp exoskeleton is depicted in Figure 1. Previously, authors performed the extraction of chitosan at lab-scale and used this experimental data to simulate the scaling up of such process using Aspen Plus ${ }^{\circledR}$ software [21]. The extended mass and energy balances provided by the software were used to perform the NuDIST tool.

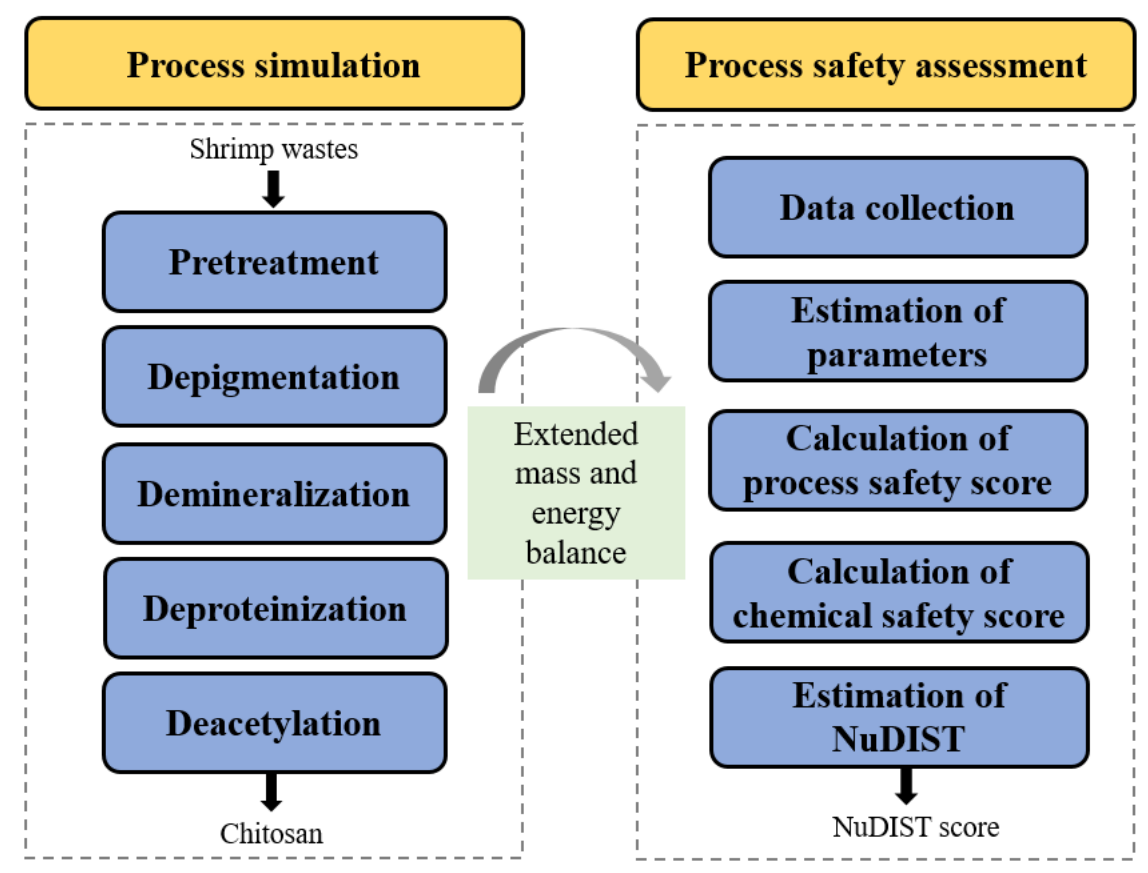

Figure 1. Schematic representation of the methodology.

\subsection{Process Description}

Figure 2 shows the process diagram for chitosan extraction from shrimp wastes with the following stages:

- Pretreatment

- Depigmentation

- Demineralization

- Deproteinization

- Deacetylation 
The reactions taking place in each stage were collected from the literature and are summarized in Table 2. The first step in the production of chitosan from shrimp waste is the pretreatment that includes: (1) washing to eliminate impurities, (2) drying to reduce moisture content, and (3) crushing to reduce particle size up to $0.5 \mathrm{~mm}$. The resulting material is fed into depigmentation stage to mix with $85 \%$ vol. ethanol, the latter is used to drag the astaxanthin from the chitin. Inter-stage neutralizations are needed to adjust the $\mathrm{pH}$ at 7 before entering to the following reaction process. During demineralization, the reactions taking place are the formation of chlorides from carbonates using hydrochloric acid. The chitin-reach stream is sent to the deproteinization stage to separate proteins with a solution of $\mathrm{NaOH}$ [21]. The extracted chitin undergoes a deacetylation process at high temperatures and basic environments to produce chitosan. This product is finally filtered, washed, and dried for further commercialization [22].

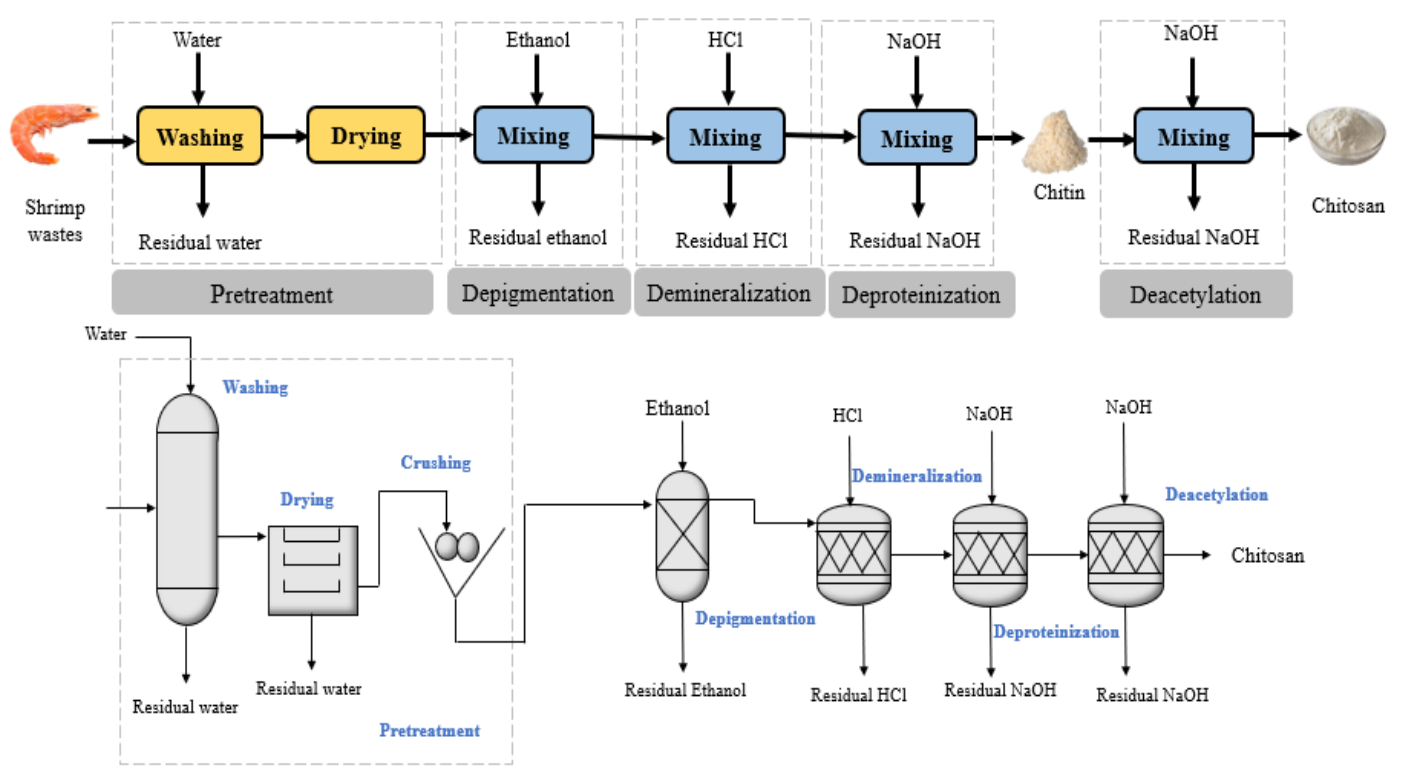

Figure 2. Simplified representation of chitosan production from shrimp wastes.

Table 2. Chemical reactions for demineralization, deproteinization, and deacetylation stages.

\begin{tabular}{ccc}
\hline Stage & Reactions & Source \\
\hline Deacetylation & $\mathrm{C}_{8} \mathrm{H}_{15} \mathrm{NO}_{6}+\mathrm{NaOH} \rightarrow \mathrm{C}_{6} \mathrm{H}_{13} \mathrm{NO}_{5}+\mathrm{C}_{2} \mathrm{H}_{3} \mathrm{NaO}_{2}$ & [23] \\
\hline \multirow{5}{*}{ Demineralization } & $\mathrm{CaCO}_{3}+2 \mathrm{HCl} \rightarrow \mathrm{CaCl}_{2}+\mathrm{H}_{2} \mathrm{O}+\mathrm{CO}_{2}$ & \\
& $\mathrm{Na}_{2} \mathrm{CO}_{3}+2 \mathrm{HCl} \rightarrow 2 \mathrm{NaCl}+\mathrm{H}_{2} \mathrm{O}+\mathrm{CO}_{2}$ & {$[21,23]$} \\
& $\mathrm{MgCO}_{3}+2 \mathrm{HCl} \rightarrow \mathrm{MgCl}_{2}+\mathrm{H}_{2} \mathrm{O}+\mathrm{CO}_{2}$ & \\
& $\mathrm{Ca}_{3}\left(\mathrm{PO}_{4}\right)_{2}+6 \mathrm{HCl} \rightarrow 3 \mathrm{CaCl}_{2}+2 \mathrm{H}_{3} \mathrm{PO}_{4}$ & \\
\hline & $\mathrm{C}_{6} \mathrm{H}_{12} \mathrm{~N}_{2} \mathrm{O}_{3}+2 \mathrm{NaOH} \rightarrow 2 \mathrm{C}_{3} \mathrm{H}_{6} \mathrm{NNaO}_{2}+\mathrm{H}_{2} \mathrm{O}$ \\
& $\mathrm{C}_{10} \mathrm{H}_{16} \mathrm{~N}_{2} \mathrm{O}_{7}+2 \mathrm{NaOH} \rightarrow 2 \mathrm{C}_{5} \mathrm{H}_{8} \mathrm{NNaO}_{4}+\mathrm{H}_{2} \mathrm{O}$ & \\
\hline \multirow{5}{*}{ Deproteinization } & $\mathrm{C}_{18} \mathrm{H}_{20} \mathrm{~N}_{2} \mathrm{O}_{3}+2 \mathrm{NaOH} \rightarrow 2 \mathrm{C}_{9} \mathrm{H}_{10} \mathrm{NNaO}_{2}+\mathrm{H}_{2} \mathrm{O}$ & \\
& $\mathrm{C}_{10} \mathrm{H}_{20} \mathrm{~N}_{2} \mathrm{O}_{3} \mathrm{~S}_{2}+2 \mathrm{NaOH} \rightarrow 2 \mathrm{C}_{9} \mathrm{H}_{10} \mathrm{NNaO}_{2}+\mathrm{H}_{2} \mathrm{O}$ & \\
& $\mathrm{C}_{12} \mathrm{H}_{26} \mathrm{~N}_{4} \mathrm{O}_{3}+2 \mathrm{NaOH} \rightarrow 2 \mathrm{C}_{6} \mathrm{H}_{13} \mathrm{~N}_{2} \mathrm{NaO}_{2}+\mathrm{H}_{2} \mathrm{O}$ & \\
\hline
\end{tabular}

Gathering of Process Data from Computer-Aided Simulation

The simulation of large-scale chitosan from shrimp wastes performed via Aspen Plus ${ }^{\circledR}$ provided process data such as extended mass and energy balances around the system. The chemical composition of shrimp exoskeleton was modeled considering amino acids, fatty acids, carbonates, and pigment, that are available in the software database. The processing capacity corresponds to 57,000 tons shrimp wastes per year following a previous work [21]. The thermodynamic model for property estimations was the electrolyte non-random two-liquid (eNRTL) model owing to the use of aqueous acids and bases 
within the process. All reactors for demineralization, deproteinization, and deacetylation stages were modeled as stoichiometric reactors (RStoic) using the reaction conversions found in the literature [21,23]. Table 3 lists the mass composition of the main process streams gathered from the simulation. The process flowsheet of producing chitosan from shrimp exoskeleton is depicted in Figure 3.

Table 3. Mass composition of main process streams.

\begin{tabular}{|c|c|c|c|c|c|}
\hline Stream Name & SSHRIMP & RWATER1 & ETHANOL & RETHANOL & CSHDRY \\
\hline Mass Flow Rate (kg/h) & 6602.0 & 6502.4 & $27,714.0$ & $27,850.8$ & 6365.3 \\
\hline \multicolumn{6}{|c|}{ Mass composition (wt.) } \\
\hline METHY-01 & 0.0640 & 0.0009 & 0.0000 & 0.0000 & 0.0000 \\
\hline ASTAX-01 & 0.0041 & 0.0000 & 0.0000 & 0.0011 & 0.0000 \\
\hline CALCI-01 & 0.0513 & 0.0000 & 0.0000 & 0.0000 & 0.0588 \\
\hline CALCI-02 & 0.1290 & 0.0000 & 0.0000 & 0.0000 & 0.1478 \\
\hline SODIU-01 & 0.0262 & 0.0000 & 0.0000 & 0.0000 & 0.0300 \\
\hline MAGNE-01 & 0.0152 & 0.0000 & 0.0000 & 0.0000 & 0.0174 \\
\hline L-ALA-01 & 0.0645 & 0.0000 & 0.0000 & 0.0000 & 0.0739 \\
\hline CARBO-01 & 0.0000 & 0.0000 & 0.0000 & 0.0000 & 0.0000 \\
\hline MAGNE-02 & 0.0000 & 0.0000 & 0.0000 & 0.0000 & 0.0000 \\
\hline CALCI-03 & 0.0000 & 0.0000 & 0.0000 & 0.0000 & 0.0000 \\
\hline HYDRO-01 & 0.0000 & 0.0000 & 0.0000 & 0.0000 & 0.0000 \\
\hline D-N-A-01 & 0.3000 & 0.0000 & 0.0000 & 0.0038 & 0.3269 \\
\hline L-GLU-01 & 0.1113 & 0.0000 & 0.0000 & 0.0000 & 0.1275 \\
\hline L-PHE-01 & 0.0420 & 0.0000 & 0.0000 & 0.0000 & 0.0481 \\
\hline ORTHO-01 & 0.0000 & 0.0000 & 0.0000 & 0.0000 & 0.0000 \\
\hline METHI-01 & 0.0377 & 0.0000 & 0.0000 & 0.0000 & 0.0432 \\
\hline LYSIN-01 & 0.1103 & 0.0000 & 0.0000 & 0.0000 & 0.1264 \\
\hline WATER & 0.0446 & 0.9990 & 0.1500 & 0.1493 & 0.0000 \\
\hline ETHAN-01 & 0.0000 & 0.0000 & 0.8500 & 0.8458 & 0.0000 \\
\hline SODIU-02 & 0.0000 & 0.0000 & 0.0000 & 0.0000 & 0.0000 \\
\hline SODIU-03 & 0.0000 & 0.0000 & 0.0000 & 0.0000 & 0.0000 \\
\hline CHITOSAN & 0.0000 & 0.0000 & 0.0000 & 0.0000 & 0.0000 \\
\hline SODIU-04 & 0.0000 & 0.0000 & 0.0000 & 0.0000 & 0.0000 \\
\hline Stream Name & CHITIWET2 & RWATER3 & CHITOWET & CHITWET4 & RWATER4 \\
\hline Mass Flow Rate (kg/h) & $141,921.3$ & $197,886.0$ & $100,789.0$ & $401,939.0$ & $489,905.4$ \\
\hline \multicolumn{6}{|c|}{ Mass composition (wt.) } \\
\hline METHY-01 & 0.0000 & 0.0000 & 0.0000 & 0.0000 & 0.0000 \\
\hline ASTAX-01 & 0.0000 & 0.0000 & 0.0000 & 0.0000 & 0.0000 \\
\hline CALCI-01 & 0.0000 & 0.0000 & 0.0000 & 0.0000 & 0.0000 \\
\hline CALCI-02 & 0.0000 & 0.0000 & 0.0000 & 0.0000 & 0.0000 \\
\hline SODIU-01 & 0.0000 & 0.0000 & 0.0000 & 0.0000 & 0.0000 \\
\hline MAGNE-01 & 0.0000 & 0.0000 & 0.0000 & 0.0000 & 0.0000 \\
\hline L-ALA-01 & 0.0000 & 0.0000 & 0.0000 & 0.0000 & 0.0000 \\
\hline CARBO-01 & 0.0000 & 0.0000 & 0.0000 & 0.0000 & 0.0000 \\
\hline MAGNE-02 & 0.0000 & 0.0000 & 0.0000 & 0.0000 & 0.0000 \\
\hline CALCI-03 & 0.0000 & 0.0000 & 0.0000 & 0.0000 & 0.0000 \\
\hline HYDRO-01 & 0.0066 & 0.0047 & 0.0000 & 0.0039 & 0.0033 \\
\hline D-N-A-01 & 0.0145 & 0.0018 & 0.0000 & 0.0000 & 0.0000 \\
\hline L-GLU-01 & 0.0000 & 0.0000 & 0.0000 & 0.0000 & 0.0000 \\
\hline L-PHE-01 & 0.0000 & 0.0000 & 0.0000 & 0.0000 & 0.0000 \\
\hline ORTHO-01 & 0.0000 & 0.0000 & 0.0000 & 0.0000 & 0.0000 \\
\hline METHI-01 & 0.0000 & 0.0000 & 0.0000 & 0.0000 & 0.0000 \\
\hline LYSIN-01 & 0.0000 & 0.0000 & 0.0000 & 0.0000 & 0.0000 \\
\hline WATER & 0.9743 & 0.9902 & 0.9643 & 0.9852 & 0.9908 \\
\hline ETHAN-01 & 0.0000 & 0.0000 & 0.0000 & 0.0000 & 0.0000 \\
\hline SODIU-02 & 0.0000 & 0.0000 & 0.0156 & 0.0000 & 0.0000 \\
\hline SODIU-03 & 0.0046 & 0.0033 & 0.0000 & 0.0057 & 0.0050 \\
\hline CHITOSAN & 0.0000 & 0.0000 & 0.0138 & 0.0035 & $3.0 \mathrm{E}-06$ \\
\hline SODIU-04 & 0.0000 & 0.0000 & 0.0063 & 0.0016 & 0.0013 \\
\hline
\end{tabular}




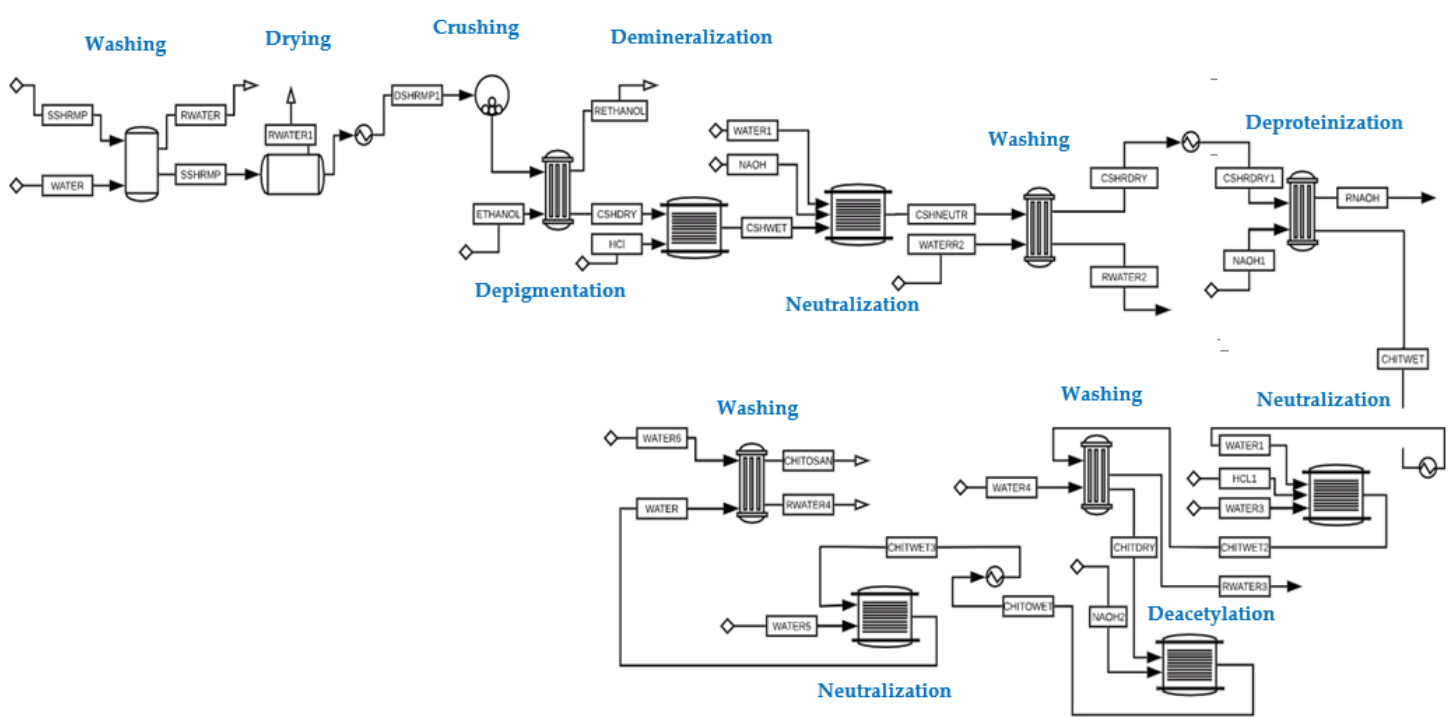

Figure 3. Process flowsheet of the simulated chitosan production from shrimp exoskeleton

\subsection{Process Safety Assessment}

The safety assessment of large-scale chitosan production via the NuDIST safety indicator was conducted following the methodological procedure described by Ahmad et al. [15]. The chemical safety parameters analyzed by this metric are explosiveness (EXP), flammability (FL), and toxicity (TOX). To determine the numerical values of the selected parameters, safety data of substances was gathered. Properties such as flash point, the upper and lower explosion limits, and the Threshold Limit Value-Short-Term Exposure Limit (TLV-STEL) toxicity value were found in the Material Safety Data Sheet (MSDS) of the chemicals. The hazards associated with process chemicals were quantified by the following logistic equations:

$$
\begin{gathered}
\text { Flammability }\left(\mathrm{S}_{\mathrm{FL}}\right) \mathrm{S}_{\mathrm{FL}}=100 \cdot\left(1-\left(\frac{1}{1+3.03 \mathrm{e}^{-0.02 x}}\right)\right) \\
\text { Explosiveness (SEXP) } \mathrm{S}_{\mathrm{EXP}}=100 \cdot\left(\frac{1}{1+1096.63 \mathrm{e}^{-0.14 x}}\right) \\
\text { Toxicity (STOX) } \mathrm{S}_{\mathrm{TOX}}=100 \cdot\left(1-\left(\frac{1}{1+403.4288 \mathrm{e}^{-0.012 x}}\right)\right)
\end{gathered}
$$

The flash point and TLV-STEL toxicity values correspond to the variable $(\mathrm{x})$ inthe logistic function of the flammability and toxicity parameters, respectively. For the explosivity parameter, the difference between the upper and lower explosion limit values (UEL-LEL) was entered. The chemical safety total score (CSTS) was estimated as given by Equation (4).

$$
\mathrm{CSTS}=\mathrm{S}_{\mathrm{FL}}+\mathrm{S}_{\mathrm{EP}}+\mathrm{S}_{\mathrm{TOX}}
$$

Subsequently, a safety assessment of the process involving the parameters of temperature (T), pressure $(\mathrm{P})$, and heat of reaction (HR) was performed using Equations (5)-(9). The highest temperature and pressure of the process units were considered for calculations as they represent the worst-case scenario. The global heat of reaction was estimated from the enthalpy of formation of substances involved in demineralization, deproteinization, and deacetylation reactions. These values were entered into the logistic equations of the NuDIST method providing a temperature, pressure, and reaction heat score. 
Temperature $\left(\mathbf{S}_{\mathrm{T}}\right)$

$$
\mathrm{S}_{\mathrm{T}}>25^{\circ} \mathrm{C}=100 \cdot\left(\frac{1}{1+403.43 \mathrm{e}^{-0.012 x}}\right)
$$

$$
\mathrm{S}_{\mathrm{T}}<25^{\circ} \mathrm{C}=100 \cdot 1-\left(\left(\frac{1}{1+0.0025 \mathrm{e}^{-0.012 x}}\right)\right)
$$

Pressure $\left(\mathrm{S}_{\mathrm{P}}\right)$

$$
\begin{gathered}
\mathrm{S}_{\mathrm{P}}=100 *\left(\frac{1}{1+148.41 \mathrm{e}^{-0.2 x}}\right) \\
\mathrm{S}_{\mathrm{HR}>0 \frac{\mathrm{kJ}}{\mathrm{mol}}}=100 \cdot\left(\frac{1}{1+601.85 \mathrm{e}^{-0.016 x}}\right)
\end{gathered}
$$

Heat of reaction (HR)

$$
\mathrm{S}_{\mathrm{HR}<0 \frac{\mathrm{kJ}}{\mathrm{mol}}}=100 \cdot\left(\frac{1}{1+403.43 \mathrm{e}^{-0.006 x}}\right)
$$

The total safety score of the process (PSTS) was calculated as follows:

$$
\mathrm{PSTS}=\mathrm{S}_{\mathrm{T}}+\mathrm{S}_{\mathrm{P}}+\mathrm{S}_{\mathrm{HR}}
$$

Finally, the total chemical safety score and the process safety score was incorporated into the total NuDIST score of the process using the Equation (11). The value of this safety indicator was compared with other processes to analyze the safety of chitosan production from shrimp exoskeleton and identify opportunities for improvements.

$$
\text { NuDIST Total Score }=\text { CSTS }+ \text { PSTS }
$$

\section{Results and Discussion}

\subsection{Chemical Safety Assessment}

Figure 4 depicts the contributions of substances to the highest values of flammability, explosiveness, and toxicity parameters. The parameter estimations for each compound in the process stages are listed in the Appendix A (see Table A1). The flammability parameter reached the highest value for ethanol at 70.44, followed by L-alanine at 36.74. The values for astaxanthin, phenylalanine, and lysine were less than 1, suggesting that they are safer in terms of fire hazards. Ethanol is also responsible for the explosiveness parameter calculated at 0.82 . For toxicity parameters, substances involved in the demineralization stage such as carbonates and chlorides have significant contributions. Calcium phosphate, calcium chloride, phosphoric acid, magnesium chloride, magnesium carbonate, and sodium hydroxide showed similar hazards when exposed by inhalation, ingestion, or dermal absorption $\left(\mathrm{S}_{\mathrm{TOX}}\right.$ =99.75). The maximum CSTS was estimated at 171.01 for large-scale chitosan production. This result was compared with those found in the literature for energy systems such as palm oil production and petrochemical industry. According to Ahmad et al. [14], the methyl methacrylate manufacturing process under six different routes reached a CSTS of around 240-342, which are significantly higher than those obtained in this work. For the recovery of palm oil using different solvents [18], the CSTS values ranged 191-198 when handling chemical substances such as cyclohexane, n-hexane, and 2-pentanone.

Figure 5 shows the ranking of most hazardous chemicals according to the values of CSTS (>99). The compounds at the top of the ranking must receive special attention when implementing safeguards at the design phase. Results reported that ethanol is the most hazardous chemical in the large-scale production of chitosan from shrimp wastes with a CSTS value of 170.65 followed by calcium carbonate, and calcium phosphate with 102.87 and 99.75, respectively. The hydrochloric acid and magnesium chloride showed CSTS values of 99.74. The presence of hazards associated with chemical handling is similar for compounds in rank position 1-7 because of the similarity in the toxicity parameter. Based on the chemical safety assessment, the use of ethanol in the depigmentation stage presents the highest risks for chitosan production from shrimp wastes. Alternative solvents such as vegetable oils (e.g., sunflower oil, coconut oil, or palm oil) must be considered in future for astaxanthin removal [24]. This corresponds to the green extraction methods addressed at lab-scale $[25,26]$. 


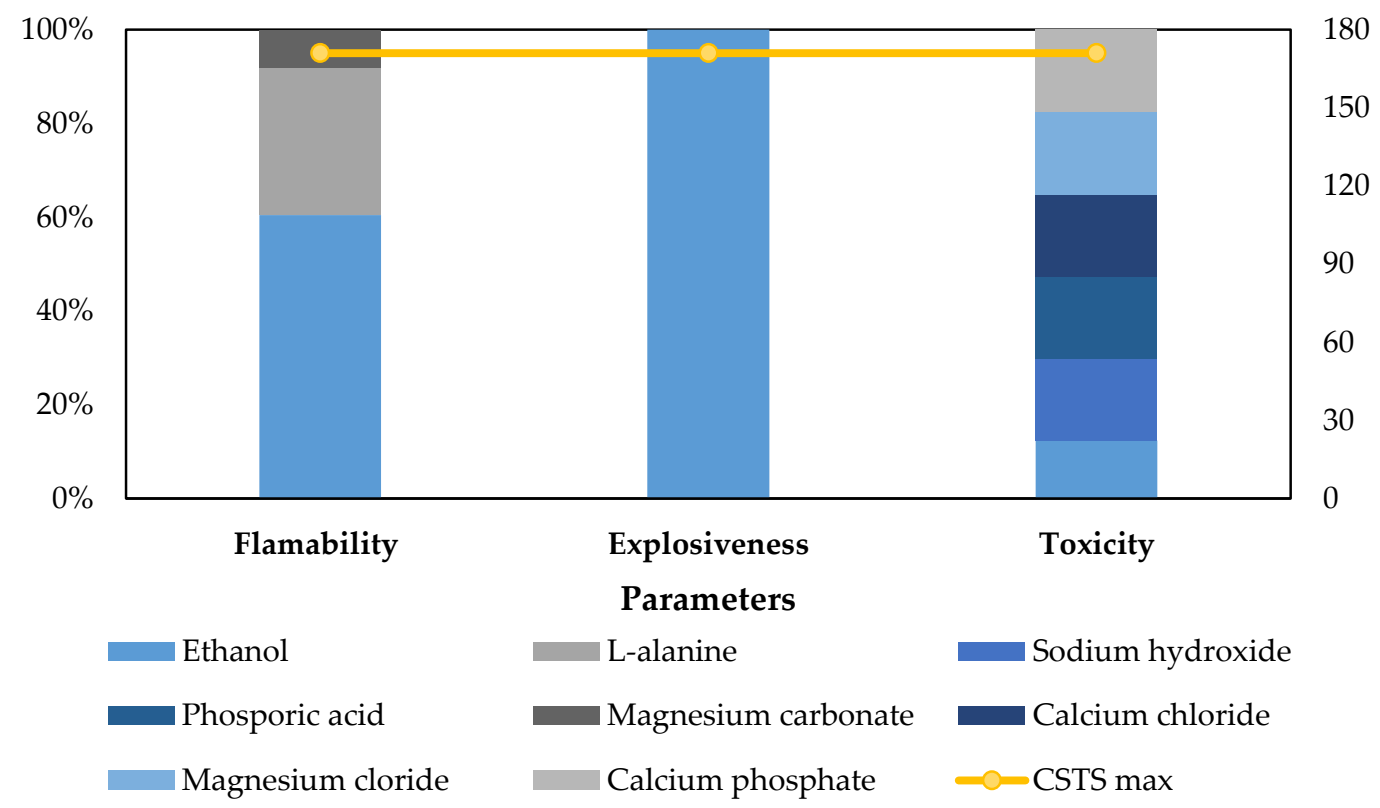

Figure 4. Contribution of chemicals to the highest values of flammability, explosiveness, and toxicity safety parameters.

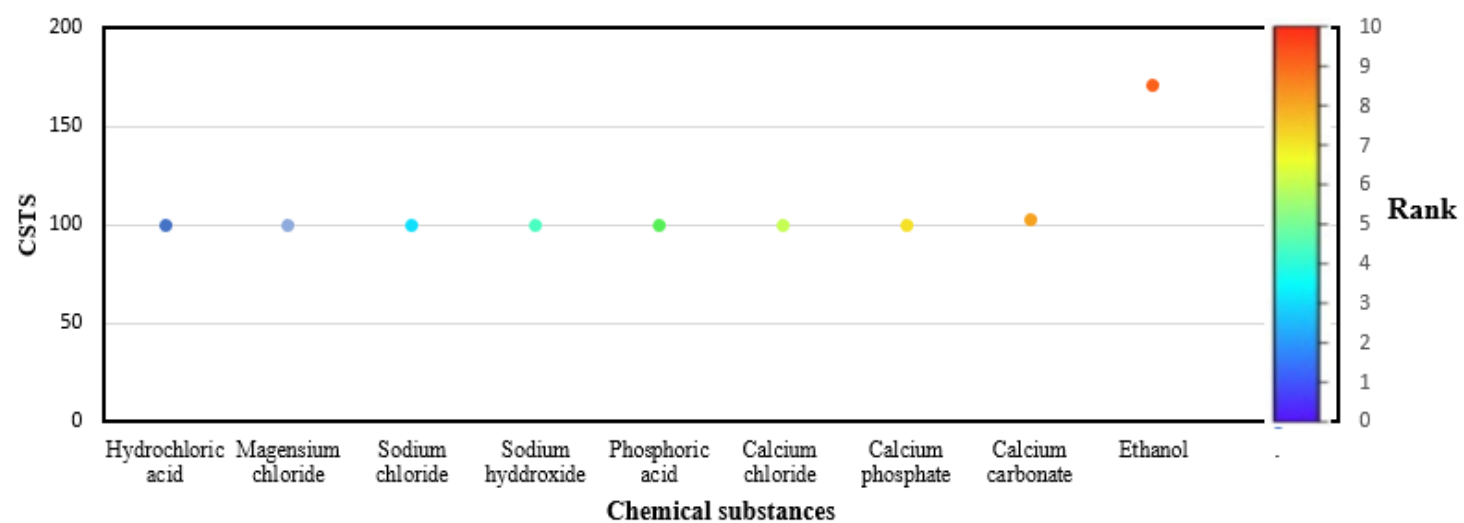

Figure 5. Rank of CSTS score estimated for chemicals in the large-scale production of chitosan from shrimp wastes.

\subsection{Process Safety Assessment}

Table 4 summarizes the score for safety parameters related to process operation. The temperature and pressure scores are the same for the stages as averaged operating conditions were set with the inlet and outlet streams of each equipment $\left(\mathrm{T}=36.48^{\circ} \mathrm{C}\right.$ and $\left.\mathrm{P}=1 \mathrm{bar}\right)$. The demineralization and deacetylation stages reached the highest values for heat reaction score suggesting that the design of large-scale chitosan production must consider safeguards in reactors at which such endothermic reactions take place. The PSTS score corresponded to 101.09, 101.19, and 9.29 for deacetylation, demineralization, and deproteinization stages, respectively. The maximum PSTS was quantified at 209.20 by considering the sum of HR scores per stage. This result was similar to those reported for methyl methacrylate (MMA) production based on the routes of acetone cyanohydrin and ethylene via propionaldehyde (PSTSmax $=241$ and 232, respectively); however, it was higher than for the routes of ethylene via methyl propionate, propylene, and tertiary butyl alcohol [14].

The NuDIST score was calculated at 380.20 in the production of chitosan from shrimp exoskeleton. The level of risk according to this estimation is light following the analysis conducted by Sudarni et al. [27] for the characterization of risk assessments. Compared to other works, the selected process is inherently safer owing to the organic nature of chitosan source (exoskeleton) and less drastic 
operating conditions. Figure 6 depicts a comparison in NuDIST estimation for the petrochemical industry case study [14] and this work. The routes of acetone cyanohydrin ( $\mathrm{ACH})$, ethylene through propionaldehyde (C2/PA), ethylene through methyl propionate (C2/MP), and propylene (C3) reported a score of 499, 574, 493, and 531, respectively, which represents a moderate level of risk.

Table 4. Process safety assessment for the large-scale production of chitosan from shrimp wastes.

\begin{tabular}{cccc}
\hline Safety Parameters Per Stage & HR Score & Temperature Score & Pressure Score \\
\hline Deacetylation & 99.90 & & \multirow{2}{*}{0.8163} \\
\hline Demineralization & 100.00 & 0.3826 & \\
\hline Deproteinization & 8.10 & & 0.8163 \\
\hline Total & 208.00 & & 0.3826 \\
\hline Total safety score of the process (PSTS)max & & 209.20 & \\
\hline NuDIST Score & & 380.20 & \\
\hline
\end{tabular}

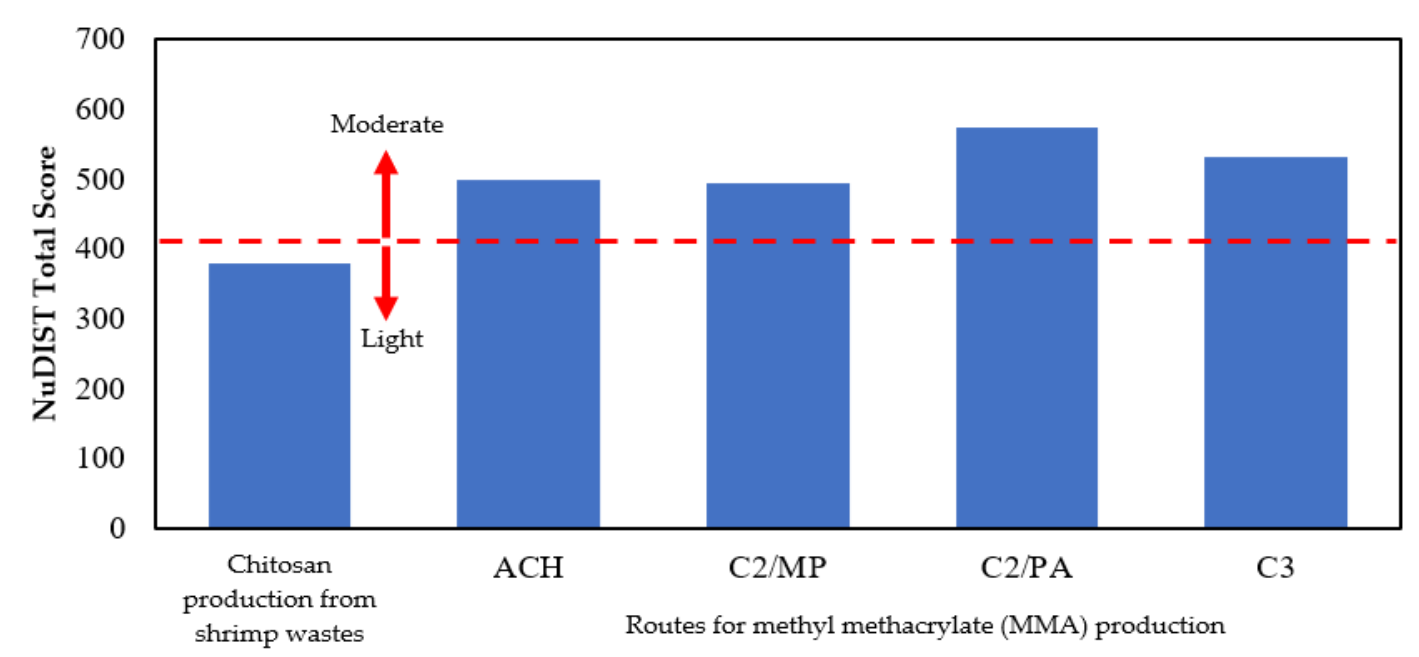

Figure 6. Comparison of NuDIST results for chitosan production and other processes.

\section{Conclusions}

An inherent safety assessment methodology was applied to the large-scale production of chitosan from shrimp wastes to identify the presence of hazardous associated with chemical substances and process operation. The selected numerical descriptive inherent safety (NuDIST) technique was focused on three chemical parameters (flammability, explosiveness, and toxicity) and three process parameters (temperature, pressure, and heat of reaction). According to the results, ethanol was the most dangerous chemical with CSTS of 170.65 while the other ranked chemicals reported similar CSTS values around 99-102. The parameter associated with the process was estimated at 209.20, therefore, on an industrial scale, the implementation of the process to obtain chitosan from shrimp exoskeleton is considered relatively safe; however, constant control is necessary to minimize risks of explosion and fire, specifically in the stages of depigmentation and demineralization. A NuDIST total score of 380.20 was obtained, representing a light level of risk, and consequently this process design is inherently safer than other processes in petrochemical industry with moderate risks. The replacement of ethanol by vegetable oils in the depigmentation stage must be addressed as future work to estimate improvements in the safety performance of the process at large scale. The mass integration of residual streams containing agents such as $\mathrm{NaOH}$ and $\mathrm{HCl}$ should be considered within the design to reduce its consumption and waste generation. 
Author Contributions: Conceptualization, Á.D.G.-D. and K.A.M.-S.; methodology, D.A.M.-G. and D.C.-C.; software, Á.D.G.-D.; validation, Á.D.G.-D., A.Z., and D.C.-C.; formal analysis, D.A.M.-G. and Á.D.G.-D.; investigation, D.A.M.-G. and D.C.-C.; resources, Á.D.G.-D., D.A.M.-G., D.C.-C., and K.A.M.-S.; data curation, Á.D.G.-D. and A.Z.; writing—original draft preparation, D.A.M.-G., Á.D.G.-D., and D.C.-C.; writing-review and editing, K.A.M.-S., A.Z., and Á.D.G.-D.; visualization, Á.D.G.-D. and A.Z.; supervision, Á.D.G.-D. and A.Z.; project administration, Á.D.G.-D.; funding acquisition, Á.D.G.-D. All authors have read and agreed to the published version of the manuscript.

Funding: This research received no external funding.

Acknowledgments: Authors express their gratitude to the University of Cartagena and Sapienza University of Rome for providing support to conduct this research.

Conflicts of Interest: The authors declare no conflict of interest.

\section{Appendix A}

Table A1. Chemical safety parameters of explosiveness, flammability and toxicity.

\begin{tabular}{llccc}
\hline Chemical Substance & Stage(s) of the Process & $\mathrm{S}_{\mathrm{FL}}$ & $\mathrm{S}_{\mathrm{EXP}}$ & $\mathbf{S}_{\mathrm{TOX}}$ \\
\hline Astaxanthin & Pretreatment and depigmentation & 0.037 & - & - \\
\hline Calcium carbonate & Pretreatment and depigmentation & 3.13 & - & 99.74 \\
\hline Calcium chloride & Pretreatment and depigmentation & - & - & 99.75 \\
\hline Magnesium carbonate & Pretreatment and depigmentation & 9.38 & - & - \\
\hline L-alanine & $\begin{array}{l}\text { Pretreatment, depigmentation, demineralization, } \\
\text { and deproteinization }\end{array}$ & 36.74 & - & - \\
\hline Magnesium chloride & Demineralization & - & - & 99.75 \\
\hline Calcium phosphate & Demineralization & - & - & 99.75 \\
\hline Hydrochloric acid & Demineralization, neutralization, and deproteinization & - & - & 99.74 \\
\hline Glucosamine & $\begin{array}{l}\text { Pretreatment, neutralization, depigmentation, neutralization, } \\
\text { demineralization, and deproteinization }\end{array}$ & 3.20 & - & - \\
\hline Phenylalanine & $\begin{array}{l}\text { Pretreatment, depigmentation, demineralization, } \\
\text { and deproteinization }\end{array}$ & 0.66 & - & - \\
\hline Phosphoric acid & Demineralization and neutralization & - & - & 99.75 \\
\hline Lysine & $\begin{array}{l}\text { Pretreatment, depigmentation, demineralization, and } \\
\text { neutralization }\end{array}$ & 0.88 & - & - \\
\hline Ethanol & Depigmentation & 70.44 & 0.82 & 99.39 \\
\hline Sodium chloride & Demineralization, deproteinization, and deacetylation & - & - & 99.74 \\
\hline Sodium hydroxide & Neutralization, deproteinization, and deacetylation & - & - & 99.75 \\
\hline
\end{tabular}

\section{References}

1. Cahú, T.B.; Santos, S.D.; Mendes, A.; Córdula, C.R.; Chavante, S.F.; Carvalho, L.B.; Nader, H.B.; Bezerra, R.S. Recovery of protein, chitin, carotenoids and glycosaminoglycans from Pacific white shrimp (Litopenaeus vannamei) processing waste. Process Biochem. 2012, 47, 570-577. [CrossRef]

2. Hamed, I.; Ozogul, F.; Regenstein, J. Industrial applications of crustacean by-products (chitin, chitosan, and chitooligosaccharides): A review. Trends Food Sci. Technol. 2016, 48, 40-50. [CrossRef]

3. Cabarcas, M.; Marimon, W.; Miranda, M. Diseño de un proceso económico y competitivo para la extracción de quitina y producción de quitosano a partir de exoesqueletos de camarón. Doctoral Dissertation, Universidad de Cartagena, Cartagena, Colombia, 2011.

4. Elieh-Ali-Komi, D.; Hamblin, M. Chitin and Chitosan: Production and Application of Versatile Biomedical Nanomaterials. Int. J. Adv. Res. 2016, 4, 411-427.

5. Srinivasan, H.; Velayutham, K.; Ravichandran, R. Chitin and chitosan preparation from shrimp shells Penaeus monodon and its human ovarian cancer cell line, PA-1. Int. J. Biol. Macromol. 2018, 107, 662-667. [CrossRef]

6. Cogollo-Herrera, K.; Bonfante-Álvarez, H.; de Ávila-Montiel, G.; Herrera Barros, A.; González-Delgado, Á.D. Techno-economic Sensitivity Analysis of Large Scale Chitosan Production Process from Shrimp Shell Wastes. Chem. Eng. Trans. 2018, 70, 2179-2184. 
7. Islam, S. Production of chitin and chitosan from shrimp shell wastes. J. Bangladesh Agric. Univ. 2016, 14, 253-259. [CrossRef]

8. Nouri, M.; Khodaivan, F.; Razavi, S.; Mousav, M. Improvement of chitosan production from Persian Gulf shrimp waste by response surface methodology. Food Hydrocoll. 2016, 59, 50-58. [CrossRef]

9. Kishimoto, Y.; Yoshida, H.; Kondo, K. Potential Anti-Atherosclerotic Properties of Astaxanthin. Mar. Drugs 2016, 14, 35. [CrossRef] [PubMed]

10. Torres-carvajal, L.K.; González, Á.D.; Francisco, U.; Santander, D.P. Astaxanthin Production from Haematococcus pluvialis: Effects of Light Wavelength and Salinity. Contemp. Eng. Sci. 2017, 10, 1739-1746. [CrossRef]

11. Kockmann, N.; Thenée, P.; Fleischer-Trebes, C.; Laudadio, G.; Noel, T. Safety assessment in development and operation of modular continuous-flow processes. React. Chem. Eng. 2017, 2, 258-280. [CrossRef]

12. Javad, M.; Mohammadi, H.; Reniers, G.; Pouyakian, M. Exploring inherent process safety indicators and approaches for their estimation: A systematic review. J. Loss Prev. Process Ind. 2018, 52, 66-80.

13. Gerbec, M. Supporting organizational learning by comparing activities and outcomes of the safety-management system. J. Loss Prev. Process Ind. 2013, 26, 1113-1127. [CrossRef]

14. Ahmad, S.I.; Hashim, H.; Hassim, M.H. Numerical Descriptive Inherent Safety Technique (NuDIST) for inherent safety assessment in petrochemical industry. Process Saf. Environ. Prot. 2014, 92, 379-389. [CrossRef]

15. Ahmad, S.I.; Hashim, H.; Hassim, M.H.; Abdul, Z. Inherent Safety Assessment of Biodiesel Production: Flammability Parameter. Proced. Eng. 2016, 148, 1177-1183. [CrossRef]

16. Mabrouk, A.; Erdocia, X.; Alriols, M.G.; Labidi, J. Economic analysis of a biorefinery process for catechol production from lignin. J. Clean. Prod. 2018, 198, 133-142. [CrossRef]

17. Han, W.; Fang, J.; Liu, Z.; Tang, J. Techno-economic evaluation of a combined bioprocess for fermentative hydrogen production from food waste. Bioresour. Technol. 2016, 202, 107-112. [CrossRef]

18. Ahmad, S.I.; Yunus, N.A.; Hashim, H.; Rashid, R. Inherent safety assessment of solvent alternatives for palm oil recovery. Chem. Eng. Trans. 2019, 72, 49-54.

19. Ahmad, S.I.; Hashim, H.; Hassim, M. Inherent Safety Assessment Technique for Preliminary Design Stage. Chem. Eng. Trans. 2017, 56, 1345-1350. [CrossRef]

20. Aristizábal-Marulanda, V.; Poveda-Giraldo, J.A.; Cardona Alzate, C.A. Comparison of furfural and biogas production using pentoses as platform. Sci. Total Environ. 2020, 728, 138841. [CrossRef]

21. Meramo-Hurtado, S.; Alarcón-Suesca, C.; González-Delgado, Á.D. Exergetic sensibility analysis and environmental evaluation of chitosan production from shrimp exoskeleton in Colombia. J. Clean. Prod. 2020, 248. [CrossRef]

22. Trung, T.S.; Phuong, P.T.D. Bioactive compounds from by-products of shrimp processing industry in Vietnam. J. Food Drug Anal. 2012, 20, 194-197.

23. Gómez-Ríos, D.; Barrera-Zapata, R.; Ríos-Estepa, R. Comparison of process technologies for chitosan production from shrimp shell waste: A techno-economic approach using Aspen Plus ${ }^{\circledR}$. Food Bioprod. Process. 2017, 103, 49-57. [CrossRef]

24. Razi Parjikolaei, B.; Errico, M.; Bahij El-Houri, R.; Mantell, C.; Fretté, X.C.; Christensen, K.V. Process design and economic evaluation of green extraction methods for recovery of astaxanthin from shrimp waste. Chem. Eng. Res. Des. 2017, 117, 73-82. [CrossRef]

25. Luzi, F.; Puglia, D.; Sarasini, F.; Tirillò, J.; Maffei, G.; Zuorro, A.; Torre, L. Valorization and extraction of cellulose nanocrystals from north african grass: Ampelodesmos mauritanicus (diss). Carbohydr. Polym. 2019, 209, 328-337. [CrossRef] [PubMed]

26. Maffei, G.; Bracciale, M.P.; Broggi, A.; Zuorro, A.; Santarelli, M.L.; Lavecchia, R. Effect of an enzymatic treatment with cellulase and mannanase on the structural properties of nannochloropsis microalgae. Bioresour. Technol. 2018, 249, 592-598. [CrossRef]

27. Sudarni, D.H.A.; Handogo, R. Process Safety Index in Chemical Process. Int. Semin. Sci. Technol. 2016, 10-13. [CrossRef]

(C) 2020 by the authors. Licensee MDPI, Basel, Switzerland. This article is an open access article distributed under the terms and conditions of the Creative Commons Attribution (CC BY) license (http://creativecommons.org/licenses/by/4.0/). 